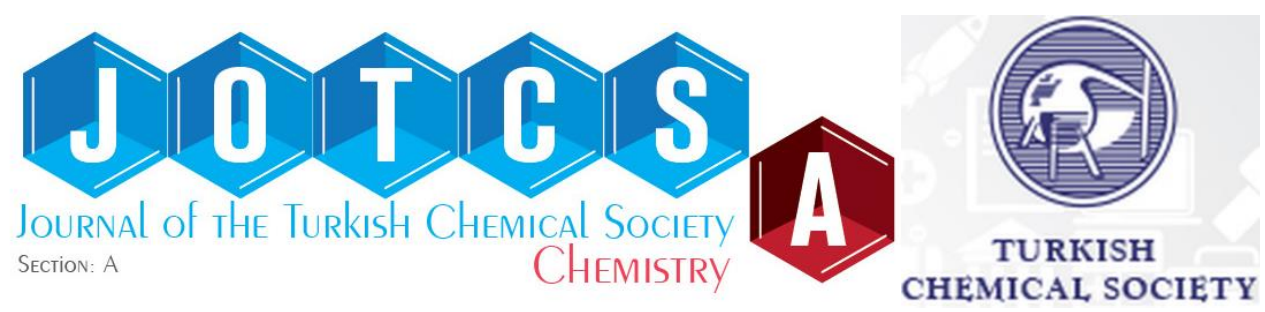

\title{
The Synthesis and Spectral Analysis of Au(III) Complex of Caffeine and Nicotinamide
}

(This article was produced from $6^{\text {th }}$ National Congress of Inorganic Chemistry and was sent to the JOTCSA editorial board for publication)

\section{Özlen ALTUN' ${ }^{1}$, Mehtap ŞUöZER \\ ${ }^{1}$ Trakya University, Department of Chemistry, 22030 Edirne/TURKEY}

\begin{abstract}
In the present study, an Au(III) complex of caffeine (CA) and nicotinamide (NA) was synthesized under reflux conditions. The structural characterization of the complex was investigated by using physico-chemical, spectral methods (UV/Vis, LC-MS, FT-IR, ${ }^{1} \mathrm{H}$ and ${ }^{13} \mathrm{C}$ NMR, XRD) and thermal analysis. The spectroscopic results of mixed ligand complex of CA and $\mathrm{NA}$ with the $\mathrm{Au}$ (III) suggested that $\mathrm{N}_{9}$ and $\mathrm{N}_{1}$ atoms of the ligands are coordinated to gold ion. Based on spectral and magnetic moment measurements, the complex was identified as in square-planar structure. From these analyses, it is predicted that the complex has the form of $\left[\mathrm{Au}(\mathrm{CA})_{2}(\mathrm{NA})_{2}\right] \mathrm{Cl}_{3} .2 \mathrm{H}_{2} \mathrm{O}$.
\end{abstract}

Keywords: Caffeine, nicotinamide, Au(III), synthesis, spectroscopy.

Submitted: May 22, 2017. Accepted: July 02, 2017.

Cite this: Altun Ö, Şuözer M. The Synthesis and Spectral Analysis of Au(III) Complex of Caffeine and Nicotinamide. JOTCSA. 2017 Jul;4(sp. is. 1):1-10.

DOI: $10.18596 /$ jotcsa.315233.

*Corresponding author. E-mail: ozlenaltun@yahoo.com 


\section{INTRODUCTION}

The purine alkoloid caffeine (CA), 1,3,7-trimethylxanthine, is an important component of many popular drinks, especially coffee and tea, but most chemists know little about its molecular and biochemistry (1). Caffeine is well known as a antimalarial agent and has the ability to solubilize a wide variety of therapeutic drugs. While there are many reports about its anticancer and antioxidant properties, there is also a strong belief that consumption in high amounts of caffeine carries a higher risk of osteoid problems developing, including osteoporosis, as well as problems with metal absorption, excretion and readsorption processes in intestines and kidneys (2).

Nicotinamide (NA) is a component of both co-enzyme of nicotinamide adenine dinucleotide (NAD) and vitamin B complex (3). These are very important to transfer hydrogen in cell respiration. The presence of the pyridine ring in which are adducts of nicotinamide numerous naturally abundant compounds is also of scientific interest. Therefore, the structure of nicotinamide has been the subject of many studies $(4,5)$.

The chemical structures of nicotinamide and caffeine are shown below. Structurally, caffeine contains two aromatic rings that affect the solubility of the aromatic hydrotropic agent (6-8). In Scheme 1 , caffeine has a methyl group at the $\mathrm{N}_{7}$ site, which blocks the interaction of metal cations with the $\mathrm{N}_{7}$ atom. $\mathrm{N}_{1}$ and $\mathrm{N}_{3}$ are also blocked by the methyl group. Thus, in caffeine $\mathrm{N}_{9}$ atom is the target of metal cation interaction, while the major binding site in nicotinamide is the $\mathrm{N}_{1}$ atom (9).<smiles>Cn1c(=O)c2c(ncn2C)n(C)c1=O</smiles>

Caffeine

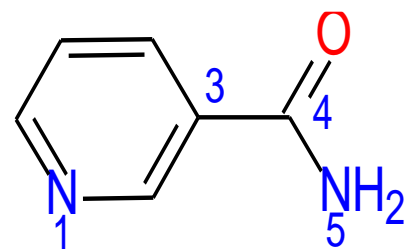

Nicotinamide

Scheme 1: The structures of caffeine and nicotinamide.

In the present study, the preparation and structural elucidation of the Au(III) complex of mixed ligand $\mathrm{CA}$ and NA is undertaken by using different methods such as physico-chemical, spectroscopic methods (UV/Vis, Mass (LC-MS), FT-IR, ${ }^{1} \mathrm{H} N M R,{ }^{13} \mathrm{C}$ NMR and XRD) and thermal analysis. 
Altun Ö, Şuözer M. JOTCSA. 2017; 4 (sp. is. 1): 1-10.

RESEARCH ARTICLE

\section{EXPERIMENTAL}

\section{Materials and measurements}

All reagents were purchased from commercial sources and used as supplied. The magnetic moment results were obtained from MK-1 Sherwood scientific magnetic susceptibility balance. Conductivity measurements were determined in DMSO using an Inolab Thermal 740P. Elemental analyses for $\mathrm{C}, \mathrm{H}$ and $\mathrm{N}$ were recorded with a Costech elemental analyzer. UV/Vis spectra were performed with a Shimadzu UV-1700 Pharma spectrophotometer in the 200-800 nm range. For the mass (LC-MS) spectra, we used an AB-SCIEX Triple TOF 4600 System. FT-IR spectra were measured with a Shimadzu IR-470 spectrometer as $\mathrm{KBr}$ pellets in the frequency range 400-4000 $\mathrm{cm}^{-1} .{ }^{1} \mathrm{H}$ NMR and ${ }^{13} \mathrm{C}$ NMR spectra were obtained in DMSO on a Bruker, DPX-400 spectrometer. Shimadzu XRD-6000 was employed for the XRD analyses. The curves of thermal analyses (TG and DTA) were observed on a Seiko Exstar TG/DTA 6200 thermal analyzer in a flowing air atmosphere with a heating rate of $10{ }^{\circ} \mathrm{C}$ min $^{-1}$ using a sample size of $5-10 \mathrm{mg}$ and platinum crucibles.

\section{Synthesis of Au(III) complex}

Caffeine (CA) of $0.388 \mathrm{~g}\left(2 \times 10^{-3} \mathrm{~mol}\right)$ was dissolved in water. An aqueous solution of the metal salt was added and placed in a magnetically-stirred $25 \mathrm{~mL}$ round-bottomed flask. This was followed by the addition of an ethanolic solution $\left(0.244 \mathrm{~g}, 2 \times 10^{-3} \mathrm{~mol}\right)$ of nicotinamide (NA) at the molar ratio of $1: 2: 2(\mathrm{M}: \mathrm{CA}: \mathrm{NA})$. The system was refluxed for five hours at $75-80{ }^{\circ} \mathrm{C}$. The yellow solid material obtained was washed in water, recrystallized with ethanol:water mixture, and dried. The yields were obtained at $88 \%$. All complexes were air-stable and soluble only in organic solvents.

$\left[\mathrm{Au}(\mathrm{CA})_{2}(\mathrm{NA})_{2}\right] \mathrm{Cl}_{3} \cdot 2 \mathrm{H}_{2} \mathrm{O}$ : Yield (\%): 88. Color: Yellow. M.P. $\left({ }^{\circ} \mathrm{C}\right): 205$. Elemental Analysis (\%): Calcd.: C 34.67, H 3.72, N 17.33, O 13.21, Cl 10.99, Au 20.08; Found: C 34.46, H 3.64, N 17.29, O 13.17, Cl 10.94, Au 20.00. FT-IR $\left(\mathrm{cm}^{-1}\right): 3347.08 \mathrm{v}(\mathrm{NH}), 1692.22 \mathrm{v}(\mathrm{C}=0), 1603.76$ $v(C=N), 1499.92 v(C=C), 1221.67 v(C-N), 597.27 v(M-N)$. UV-Vis. (nm): 511, 242. Magnetic Moment (BM): Diamagnetic. Conductivity $\left(\Omega^{-1} \mathrm{~cm}^{2} \mathrm{~mol}^{-1}\right)$ : 88.00. $\mathrm{MS}(\mathrm{m} / \mathrm{z}, \mathrm{EI})$ : 968.97; Found: 969.30 .

\section{RESULTS AND DISCUSSION}

Elemental analysis $\mathrm{C}, \mathrm{H}, \mathrm{N}, \mathrm{O}$ and metal determination are in good agreement with the general formula given for the complex. The molar conductance value found for this complex at the concentration of $10^{-3} \mathrm{~mol} / \mathrm{L}$ is $86 \mathrm{ohm}^{-1} \mathrm{~mol}^{-1} \mathrm{~cm}^{2}$. The value for electrolyte in DMSO is of the order of $65-90 \mathrm{ohm}^{-1} \mathrm{~mol}^{-1} \mathrm{~cm}^{2}$. Hence, this complex can be regarded as an electrolyte (10). The magnetic moment of the $\mathrm{Au}$ (III) complex was $0.00 \mathrm{BM}$, indicating that the $\mathrm{Au}$ (III) complex is 
Altun Ö, Şuözer M. JOTCSA. 2017; 4 (sp. is. 1): 1-10.

typically a low-spin complex with square-planar structure. The value of $\mu_{\text {eff }}$ for $\mathrm{Au}^{3+}$ complex is diamagnetic. The absorption bands determined in the electronic spectra of the Au(III) complex also support a square-planar structure (11). From the magnetic and conductometric analysis, it is predicted that the complex is in the form of $\left[\mathrm{Au}(\mathrm{CA})_{2}(\mathrm{NA})_{2}\right] \cdot 2 \mathrm{H}_{2} \mathrm{O}$. The obtained complex is solid, insoluble in water, but soluble in DMSO, DMF, THF.

The mass (LC-MS) spectrum of Au(III) complex is given in Figure 1.

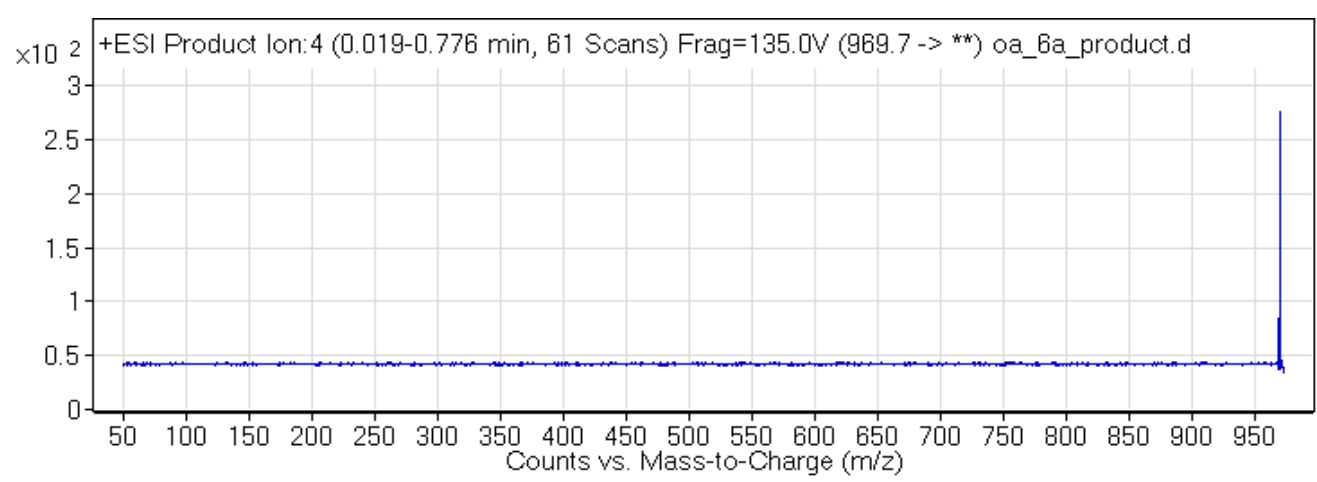

Figure 1: Mass (LC-MS) spectrum of $\left.\left[\mathrm{Au}(\mathrm{NA})_{2}(\mathrm{CA})_{2}\right] \cdot 2 \mathrm{H}_{2} \mathrm{O}\right]$

In Figure 1, there is one peak and this is in agreement with the molecular weight of the complex. This result shows that it is a complexation.

\section{UV-Visible spectra}

The UV-Visible spectra of the ligands and Au(III) complex in DMSO showed absorption bands between 290-850 $\mathrm{nm}$ (Table 1).

Table 1. UV-Visible spectra of the free ligands and Au(III) complex.

\begin{tabular}{cccc}
\hline Compound & $\boldsymbol{\Lambda}_{\max }(\mathbf{n m})$ & ABS & Assignment \\
\hline NA & 260 & 1.052 & $\Pi-\Pi^{*}$ \\
& 340 & 0.553 & $\mathrm{n}-\Pi^{*}$ \\
$\mathrm{CA}$ & 275 & 1.774 & $\Pi-\Pi^{*}$ \\
& 316 & 0.006 & $\mathrm{n}-\Pi^{*}$ \\
& 365 & 0.014 & $\mathrm{n}-\Pi^{*}$ \\
$\mathrm{Au}(\mathrm{III})$ complex & 242 & 2.552 & $\Pi \rightarrow \Pi^{*}$ and $\mathrm{n} \rightarrow \Pi^{*}$ \\
& & & ${ }^{1} \mathrm{~A}_{1 \mathrm{~g}}(\mathrm{D}) \rightarrow{ }^{1} \mathrm{E}_{\mathrm{u}}(\mathrm{D})$ \\
& 511 & 0.888 & ${ }^{1} \mathrm{~A}_{1 \mathrm{~g}}(\mathrm{D}) \rightarrow{ }^{1} \mathrm{~A}_{2 \mathrm{~g}}(\mathrm{D})$
\end{tabular}

In the UV-Visible spectra of NA, CA and Au(III) complex, the presence of a wide range of bands are due to both $n-\Pi^{*}$ and $\Pi-\Pi^{*}$ and due to a charge transfer transition arising from $n$ electron interactions between the metal and ligand that involves either a metal-to-ligand or ligand-tometal electron transfer. 
The absorption spectra of the Au(III) complex demonstrates an absorption band at $242 \mathrm{~nm}$, which is attributed to the electronic transition of ${ }^{1} \mathrm{~A}_{1 \mathrm{~g}}(D) \rightarrow{ }^{1} \mathrm{E}_{\mathrm{u}}(D)$, while the band at $511 \mathrm{~nm}$ is caused by the electronic transition of ${ }^{1} A_{1 g}(D) \rightarrow{ }^{1} A_{2 g}(D)$. These transitions and assignments indicate that the $\mathrm{Au}$ (III) complex has square-planar geometry $(12,13)$.

\section{FT-IR spectra}

The FT-IR spectra of the CA and NA and gold complex are given in Figure 2.

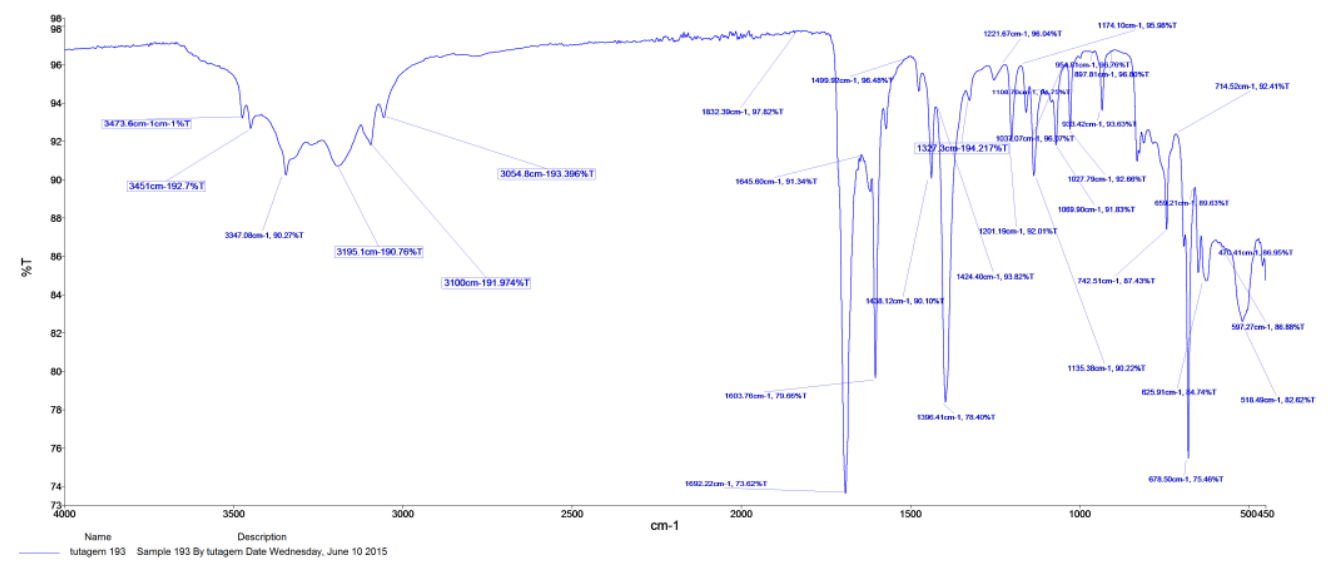

Figure 2: FT-IR spectrum of $\left.\left[\mathrm{Au}(\mathrm{NA})_{2}(\mathrm{CA})_{2}\right] \cdot 2 \mathrm{H}_{2} \mathrm{O}\right]$.

The FT-IR spectrum of CA demonstrates strong bands at 1720 and $1658 \mathrm{~cm}^{-1}$ that may be attributed to the $\mathrm{V}(\mathrm{C}=\mathrm{O})$ and $\mathrm{V}(\mathrm{C}=\mathrm{N})$ stretching frequencies, respectively $(14,15)$. These bands are shifted to lower frequencies in the complex by $1692 \mathrm{~cm}^{-1}$ and $1603 \mathrm{~cm}^{-1}$, respectively. These results indicate that the coordination of $\mathrm{CA}$ to the metal ions is through the nitrogen atom $\mathrm{N}_{9}$ (16).

In the FT-IR spectrum of NA $(14,15)$, the band at $1680 \mathrm{~cm}^{-1}$ which is assignable to nicotinamide band arising mainly from the $\mathrm{v}_{(\mathrm{C}=0)}$ stretching vibration in free NA, which is also found at the frequency range $1692 \mathrm{~cm}^{-1}$ in the Au(III) complex. The bands at $1612 \mathrm{~cm}^{-1}$ and $1255 \mathrm{~cm}^{-1}$ are due to $\mathrm{v}_{(\mathrm{C}=\mathrm{N})}$ and $\mathrm{v}_{(\mathrm{C}-\mathrm{N})}$ stretching vibrations and they move to lower wavenumbers $\left(1603 \mathrm{~cm}^{-1}\right.$ and $1221 \mathrm{~cm}^{-1}$ ) compared to free NA. The coordination through the nitrogen atom in $\mathrm{V}(\mathrm{C}=\mathrm{N})$ and $\mathrm{V}(\mathrm{C}-\mathrm{N})$ groups is further supported by the occurrence of a new band at $597 \mathrm{~cm}^{-1}$ in the spectra of the complex which may be assigned to $\mathrm{V}_{(\mathrm{M}-\mathrm{N})}(17)$. The free NA shows a medium intensity band at $3210 \mathrm{~cm}^{-1}$ assigned to $\mathrm{V}_{(\mathrm{NH})}$ vibrations, which has been observed in the $3347 \mathrm{~cm}^{-1}$ region for the complex. It can be observed that there is no considerable shift in the $v_{(\mathrm{NH})}$ vibrations in the case of the complex, compared to nicotinamide, indicating non-involvement of the amide $\mathrm{NH}$ function in coordination.

\section{${ }^{1} \mathrm{H}$ and ${ }^{13} \mathrm{C}$ spectra}

${ }^{1} \mathrm{H}$ and ${ }^{13} \mathrm{C}$ NMR data of the NA, CA and Au(III) complex are given Figure 3 and 4. 

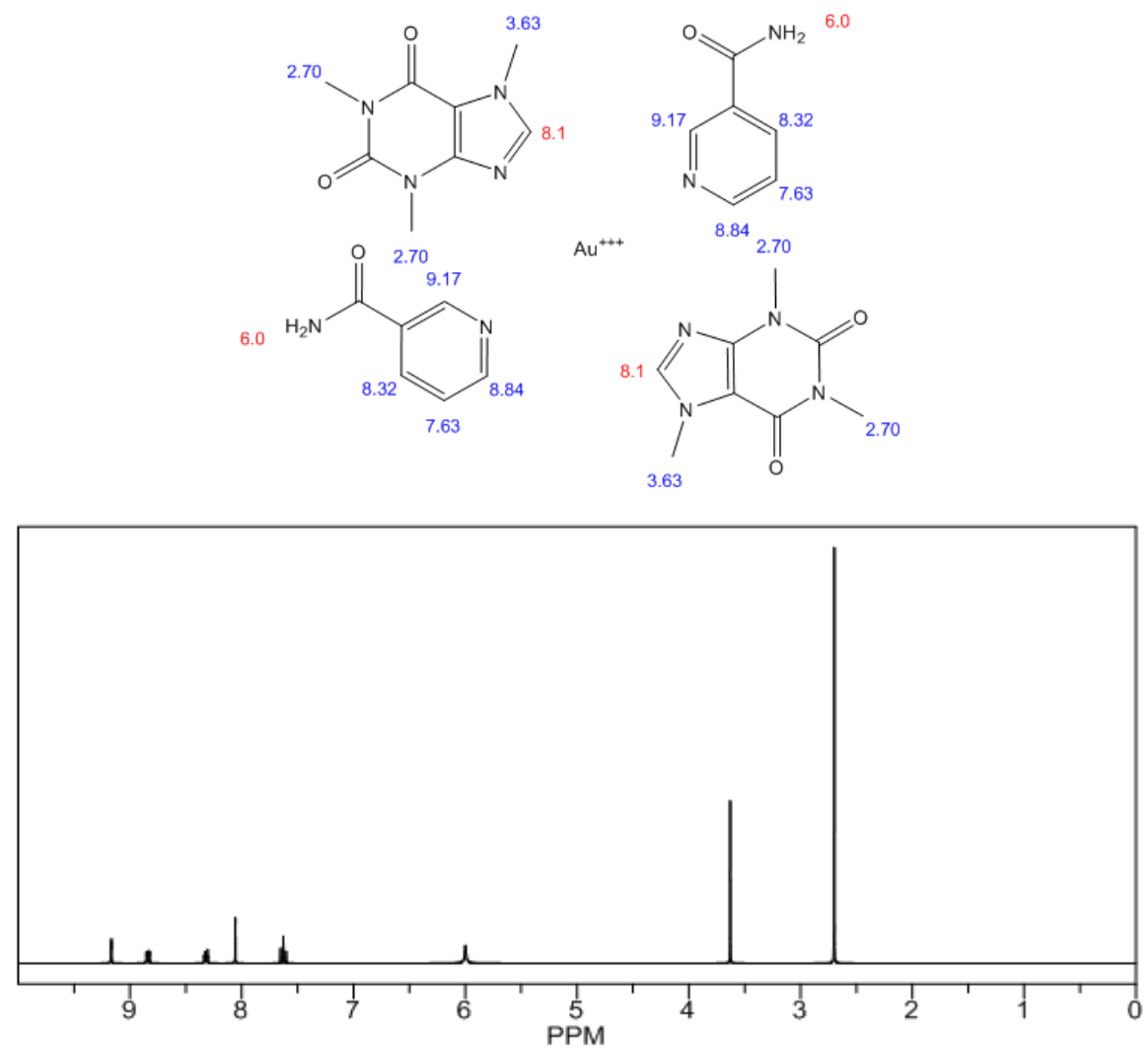

Figure 3: ${ }^{1} \mathrm{H}$ NMR spectrum of $\left.\left[\mathrm{Au}(\mathrm{NA})_{2}(\mathrm{CA})_{2}\right] .2 \mathrm{H}_{2} \mathrm{O}\right]$

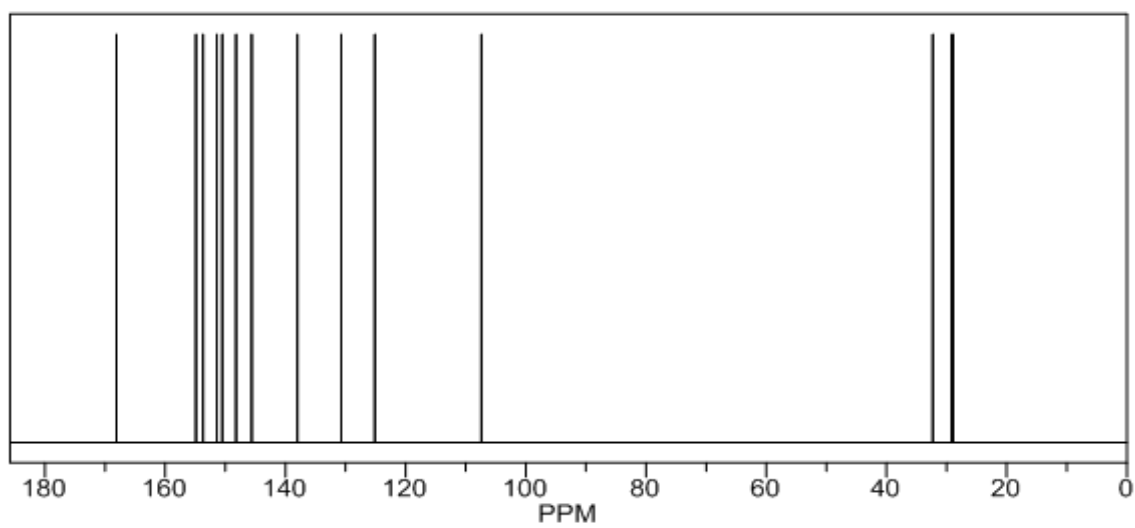

Figure 4: ${ }^{13} \mathrm{C}$ NMR spectrum of $\left.\left[\mathrm{Au}(\mathrm{NA})_{2}(\mathrm{CA})_{2}\right] \cdot 2 \mathrm{H}_{2} \mathrm{O}\right]$

The ${ }^{1} \mathrm{H}$ NMR spectra of caffeine in d-DMSO has proton signals at $\delta: 2.70\left(\mathrm{~s}, 3 \mathrm{H}, \mathrm{N}_{1}-\mathrm{CH}_{3}\right), 2.70$ $\left(\mathrm{s}, 3 \mathrm{H}, \mathrm{N}_{3}-\mathrm{CH}_{3}\right), 3.63\left(\mathrm{~s}, 3 \mathrm{H}, \mathrm{N}_{7}-\mathrm{CH}_{3}\right)$ and $8.10 \mathrm{ppm}\left(\mathrm{s}, 1 \mathrm{H}, \mathrm{C}_{8}-\mathrm{H}\right)$, while nicotinamide has signals at $\delta: 9.17\left(\mathrm{~d}, 1 \mathrm{H}, \mathrm{C}_{2}-\mathrm{H}\right), 8.32\left(\mathrm{~d}, 1 \mathrm{H}, \mathrm{C}_{4}-\mathrm{H}\right), 7.63\left(\mathrm{~m}, 1 \mathrm{H}, \mathrm{C}_{5}-\mathrm{H}\right), 8.84\left(\mathrm{~d}, 1 \mathrm{H}, \mathrm{C}_{6}-\mathrm{H}\right)$, and $6 \mathrm{ppm}$ $\left(\mathrm{s}, 2 \mathrm{H}, \mathrm{NH}_{2}\right)$.

The ${ }^{13} \mathrm{C}$ NMR spectrum of caffeine shows signals at $\delta: 27.9\left(\mathrm{~s}, \mathrm{~N}_{1}-\mathrm{CH}_{3}\right), 29.7\left(\mathrm{~s}, \mathrm{~N}_{1}-\mathrm{CH}_{3}\right), 33.5$ $\left(\mathrm{s}, \mathrm{N}_{7}-\mathrm{CH}_{3}\right), 152\left(\mathrm{~s}, \mathrm{C}_{2}\right), 149\left(\mathrm{~s}, \mathrm{C}_{4}\right), 108\left(\mathrm{~s}, \mathrm{C}_{5}\right), 155\left(\mathrm{~s}, \mathrm{C}_{6}\right)$ and $141 \mathrm{ppm}\left(\mathrm{s}, \mathrm{C}_{8}\right)$, while nicotinamide-caffeine has them at $\delta: 144\left(\mathrm{~s}, \mathrm{C}_{2}\right), 139\left(\mathrm{~s}, \mathrm{C}_{3}\right), 127\left(\mathrm{~s}, \mathrm{C}_{4}\right), 132\left(\mathrm{~s}, \mathrm{C}_{5}\right), 149$ (s, $\left.\mathrm{C}_{6}\right)$ and $170 \mathrm{ppm}\left(\mathrm{S}_{1} \mathrm{C}_{7}\right)$. According to the ${ }^{1} \mathrm{H}$ and ${ }^{13} \mathrm{C}$ NMR data, little shifting is determined in the obtained complexes. These signals support the idea that nicotinamide and caffeine are coordinated with metal ions through $\mathrm{N}_{9}$ and $\mathrm{N}_{1}(18)$. 


\section{XRD spectra}

The XRD (powder pattern) values of the complex were calculated in an X-Ray diffractometer and the unit cell parameters were recorded from $2 \theta$ values with the help of a computer. Powder XRD patterns of complex consist of seven important peaks in the range $5-50^{\circ}(2 \theta)$. The interplanar spacing (d) was calculated from the positions of intense peaks using Bragg's relationship. XRD data is given in Figure 5.

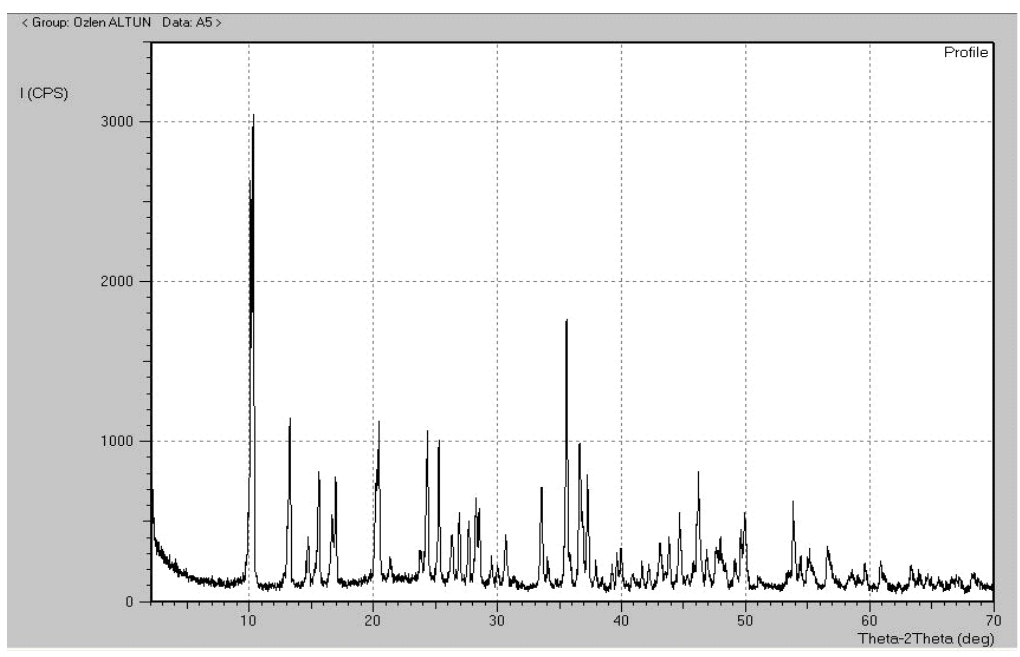

Figure 5: XRD spectrum of $\left.\left[\mathrm{Au}(\mathrm{NA})_{2}(\mathrm{CA})_{2}\right] \cdot 2 \mathrm{H}_{2} \mathrm{O}\right]$.

According to Figure 5, the $2 \theta$ values with maximum intensity of the peaks for $\mathrm{Au}$ (III) complex

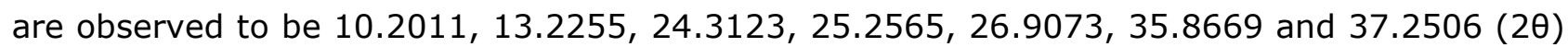
which corresponds to $d: 8.66442,6.68906,3.65805,3.52339,3.31086,2.50169$ and 2.4118, respectively. All the peaks calculated on the obtained values of interplanar distance are compared with the recorded ones. This implies that Au(III) complex has square-planar geometry in structure.

\section{Thermal Analysis}

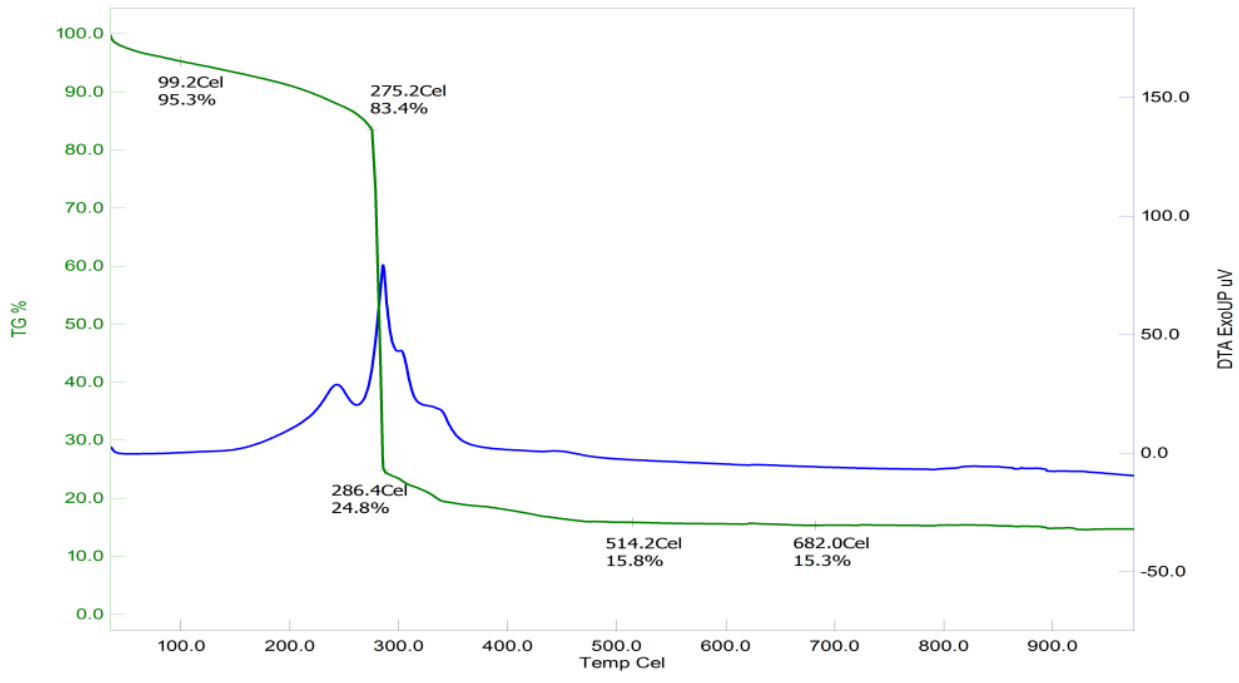

Figure 6: TG-DTA spectrum of $\left.\left[\mathrm{Au}(\mathrm{NA})_{2}(\mathrm{CA})_{2}\right] .2 \mathrm{H}_{2} \mathrm{O}\right]$ 
TG-DTA analysis was completed in the temperature range of $25^{\circ} \mathrm{C}$ and $1200{ }^{\circ} \mathrm{C}$ in static atmosphere of dry air to examine thermal stabilities of complexes. Thermal analysis data of the $\mathrm{Au}(\mathrm{III})$ complex are summarized in Figure 6.

The thermal behavior of the Au(III) complex is discussed below; the first stage decomposition is endothermic in the range of $25-200^{\circ} \mathrm{C}$ with a mass loss of $4.7 \%$, which corresponds to the loss of 2 moles of water. The second stage of decomposition is also endothermic in the range $200-500^{\circ} \mathrm{C}$, which is the decomposed organic component $(83.4 \%)$. The remaining compound over $500{ }^{\circ} \mathrm{C}$ is determined as $\mathrm{Au}(15.80 \%)$. These results are in good agreement with the suggested structures of the complex. It is confirmed that the complex contains water in the structure. As a result of the thermal study, qualitative conclusions can be made for the stability of the complex.

\section{CONCLUSION}

In the present paper, small changes in the spectral analyses were determined for the synthesized $\mathrm{Au}$ (III) complex. According to physico-chemical, spectrophotometric, and thermal analysis results, the reaction of a mixed ligand of CA and NA with $A u($ III) is a complexation reaction. Two molecules of mixed ligand react with one molecule of Au(III) ion. Accordingly, the following is the proposed structure of the mixed ligand complex of caffeine and nicotinamide in the presence of $\mathrm{Au}(\mathrm{III})$, the following complexation scheme is obtained:

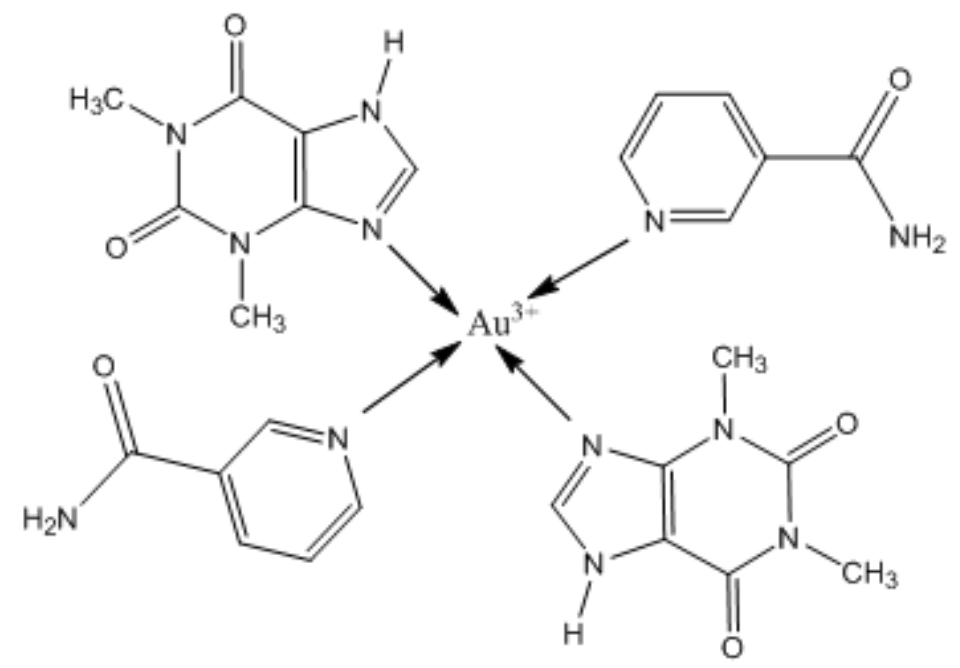

Scheme 2: Complexation of gold(III) with caffeine and nicotinamide in a $(1: 2: 2)$ ratio.

\section{ACKNOWLEDGMENT}

We thank Trakya University TUBAP-2010/72 for financial support. We (Assoc Prof Özlen ALTUN and Research Student Mehtap ŞUÖZER) confirm that "Trakya University" only provided financial support within the scope of the project for chemicals in the manuscript and we declare that the 
Altun Ö, Şuözer M. JOTCSA. 2017; 4 (sp. is. 1): 1-10.

RESEARCH ARTICLE

support received did not lead to any conflict of interests regarding the publication of this manuscript. There is no need for Trakya University's confirmation to publish this manuscript.

\section{REFERENCES}

1. Ashihara $\mathrm{H}$, Crozier A. Caffeine: a well known but little mentioned compound in plant science. Trends in plant science. 2001;6(9):407-413.

1. Massey LK. Is caffeine a risk factor for bone loss in the elderly? The American Journal of Clinical Nutrition [Internet]. 2001 [cited 2017 Jul 13];74. Available from:

http://ajcn.nutrition.org/content/74/5/569.full.pdf+html

3. Jóna E, Sirota A, Simon P, Kubranová M. Thermochemical investigation of nickel (II)-nicotinamidesolvent interactions in solid halogeno and thiocyanato complexes. Thermochimica acta. 1995;258:161173.

4. Coffman RE, Kildsig DO. Effect of nicotinamide and urea on the solubility of riboflavin in various solvents. Journal of pharmaceutical sciences. 1996;85(9):951-954.

5. Turan-Zitouni G, Sıvacı M, Kılıç FS, Erol K. Synthesis of some triazolyl-antipyrine derivatives and investigation of analgesic activity. European journal of medicinal chemistry. 2001;36(7):685-689.

6. Rasool AA, Hussain AA, Dittert LW. Solubility Enhancement of Some Water-Insoluble Drugs in the Presence of Nicotinamide and Related Compounds. Journal of Pharmaceutical Sciences. 1991

Apr;80(4):387-93.

7. Lim L-Y, Go M-L. Caffeine and nicotinamide enhances the aqueous solubility of the antimalarial agent halofantrine. European Journal of Pharmaceutical Sciences. 2000;10(1):17-28.

8. Evstigneev M, Evstigneev $V$, Santiago AH, Davies DB. Effect of a mixture of caffeine and nicotinamide on the solubility of vitamin (B 2 ) in aqueous solution. european journal of pharmaceutical sciences. 2006;28(1):59-66.

9. Izatt RM, Christensen JJ, Rytting JH. Sites and thermodynamic quantities associated with proton and metal ion interaction with ribonucleic acid, deoxyribonucleic acid, and their constituent bases, nucleosides, and and nucleotides. Chemical Reviews. 1971;71(5):439-481.

10. Geary WJ. The use of conductivity measurements in organic solvents for the characterisation of coordination compounds. Coordination Chemistry Reviews. 1971;7(1):81-122.

11. Dyer JR. Applications of absorption spectroscopy of organic compounds. 1965; 
Altun Ö, Şuözer M. JOTCSA. 2017; 4 (sp. is. 1): 1-10.

12. Lever ABP. Inorganic electronic spectroscopy. 2nd ed. Amsterdam; New York: Elsevier; 1984. 863 p. (Studies in physical and theoretical chemistry).

13. Socrates G. Infrared Characterization Group Frequencies. New York: John Wiley and Sons; 1980.

14. Nakamoto K. Infrared and Raman spectra of inorganic and coordination compounds. 6th ed. Hoboken, N.J: Wiley; 2009. 1 p.

15. Cramer RE, Ho DM, Van Doorne W, Ibers JA, Norton T, Kashiwagi M. Triphenylmethylphosphonium trichloro (caffeine) platinum (II) $[\mathrm{P}(\mathrm{C} 6 \mathrm{H} 5) 3(\mathrm{CH} 3)][\mathrm{PtCl} 3$ (caffeine)], structure and anticancer activity. Inorganic Chemistry. $1981 ; 20(8): 2457-2461$.

16. Chandra S, Gupta LK, Agrawal S. Modern spectroscopic and biological approach in the characterization of a novel 14-membered [N 4] macrocyclic ligand and its transition metal complexes. Transition Metal Chemistry. 2007;32(2):240-245.

17. Colacio-Rodriguez E, Lopez-Gonzalez J, Salas-Peregrin J. 1, 3, 8-trimethylxanthine complexes of Cu (II), Zn (II), Cd (II), and Hg (II). Canadian journal of chemistry. 1983;61(11):2506-2508.

18. Abuhijleh AL, Ali HA, Emwas A-H. Synthesis, spectral and structural characterization of dinuclear rhodium (II) complexes of the anticonvulsant drug valproate with theophylline and caffeine. Journal of Organometallic Chemistry. 2009;694(22):3590-3596. 